\title{
Effect of extractives on conferred and natural durability of Cupressus lusitanica heartwood
}

\author{
Ahmed Mohareb ${ }^{1,2}$, Peter SirmaH ${ }^{1,3}$, Lyne Desharnais ${ }^{1}$, Stéphane DumarÇAY $^{1}$, \\ Mathieu PÉTRISSANS ${ }^{1}$, Philippe GÉRARDIN ${ }^{1 *}$ \\ ${ }^{1}$ Laboratoire d'Études et de Recherche sur le Matériau Bois, IFR 110, Nancy Université, BP 70239, 54506 Vandoeuvre-lès-Nancy, France \\ ${ }^{2}$ Department of Forestry and Wood Technology, Faculty of Agriculture, 21545-El-Shatby, Alexandria University, Egypt \\ ${ }^{3}$ Wood Science and Technology Department, Moi University, P.O. Box 1125, Eldoret, Kenya
}

(Received 16 October 2009; accepted 7 December 2009)

Keywords:

Cupressus lusitanica /

durability /

extractives /

heat treatment /

decay

\begin{abstract}
- Identification of extractives present in Cupressus lusitanica heartwood has been conducted using GC-MS analyses. The chromatogram of toluene/ethanol extracts indicated the presence of large amounts of benzaldehyde and numerous terpenic compounds such as cedrol, agathadiol, epimanool, bornyl acetate, $\alpha$-cedrene and $\beta$-cedrene.

- The effect of these extractives on the natural durability of cypress wood was investigated on heart wood blocks exposed to pure culture of Poria placenta before or after solvent extraction. Weight losses revealed severe fungal degradations on the extracted blocks compared to unextracted ones.

- Efficiency of heartwood extractives as inhibitors of the growth of Poria placenta on malt/agar test confirms their contribution to cypress natural durability.

- Cypress blocks were treated at $240{ }^{\circ} \mathrm{C}$ for different times to reach different levels of thermodegradation to evaluate effect of heat treatment on fungal durability. Results indicate that evaporation of volatile extractives during the first few minutes of heat treatment contribute to decreased wood durability, while longer treatment times lead to the expected improvement of durability.

- This study suggests that the content of extractives, which may be modified during wood drying or weathering processes, could be the origin of the conflicting data described in the literature concerning cypress natural durability.
\end{abstract}

\author{
Mots-clés : \\ Cupressus lusitanica / \\ durabilité / \\ extractibles / \\ traitement thermique / \\ pourriture
}

Résumé - Effet des extractibles sur la durabilité naturelle du duramen de cyprès.

- Les extractibles présents dans le duramen de Cupressus lusitanica ont été analysés par GC-MS. Le chromatogramme des extraits obtenus à l'aide d'un mélange toluène/éthanol met en évidence des quantités importantes de benzaldéhyde et de nombreux composés terpéniques comme le cédrol, l'agathadiol, l'épimanool, l'acétate de bornyl, l' $\alpha$-cédrène et le $\beta$-cédrène.

- L'effet des extractibles sur la durabilité naturelle du cyprès a été évalué à l'aide d'essais réalisés sur des blocs préalablement extraits ou non puis exposés à Poria placenta. Les pertes de masse mettent en évidence une dégradation importante des échantillons extraits comparativement aux témoins non extraits.

- L'efficacité des extractibles comme inhibiteur de croissance de Poria placenta a été évaluée. Les résultats indiquent une forte inhibition du développement fongique.

- Des blocs de cyprès ont été traités à $240{ }^{\circ} \mathrm{C}$ pendant des temps variables pour atteindre différents niveaux de thermo-dégradation. L'évaporation des extractibles volatils durant la première phase du traitement thermique conduit à une diminution de la durabilité du bois aux agents de pourriture, alors que des traitements plus longs conduisent à l'augmentation de durabilité attendue.

- Cette étude suggère que la teneur en extractibles, susceptible de varier suite au séchage ou aux intempéries, peut être à l'origine des observations contradictoires rapportées dans la littérature concernant la durabilité naturelle du cyprès.

*Corresponding author: Philippe.Gerardin@lermab.uhp-nancy.fr 


\section{INTRODUCTION}

Kenyan forests plantations comprise $31 \%$ pines, $45 \% \mathrm{Cy}$ press, $10 \%$ Eucalypts and $14 \%$ other species, which were the main base for industrial raw materials before the logging ban effected by the government in the year 1999 (Mburu et al., 2007). Cypress (Cupressus lusitanica), also known as Mexican cypress, with a production of about 2.5 million cubic metres per annum, is the most important industrial softwood species used for timber production (Venkatasamy, 2006). The heartwood is reported to be resistant to treatment by conventional dipping processes and have an irregular response to pressurevacuum systems. Reports on durability to decay are conflicting with classification ranging from non resistant to very resistant (Scheffer and Morrell, 1998). Due to the logging ban in the government forests, there has been acute shortage of wood for construction, fencing and other purposes. Increase of population in Kenya has also contributed to depletion of the natural forests leading to shortage in industrial raw material. An alternative to reduce wood demand in Kenya is to improve wood durability through adequate preservation treatments increasing service life of wood products and consequently decreasing the consumption of wood. Because of the poor treatability of cypress and its variable durability, it seems interesting to evaluate conferred durability by heat treatment on wood decay resistance for applications where termites' hazards can be more or less controlled with constructive solutions. Indeed, heat treatment has been particularly developed in Europe during the last decade leading to commercialization of heat treated timbers from low natural durability wood species like pine, spruce, poplar or beech (Alén et al., 2002; Patzelt et al., 2002). Applied to cypress, heat treatment lead to unexpected decrease of durability in a first time followed by the expected increase of durability in a second time. This behaviour is directly associated to the presence of high amounts of extractives responsible for cypress natural durability. The aims of this work were therefore to investigate the effect of heat treatment on Cupressus lusitanica decay resistance, identify heartwood extractives and evaluate their effect on wood durability.

\section{MATERIALS AND METHODS}

\subsection{Material}

Sampling was done from cypress (Cupressus lusitanica) tree stand aged $25 \mathrm{y}$ at the time of felling from Kapsabet Forest Station, Kenya. Samples were cut from heartwood, air dried and transported to Nancy (France). Heartwood samples were further cut into small blocks for each test using a band saw and dried at $103{ }^{\circ} \mathrm{C}$ for $48 \mathrm{~h}$ before each experiment (heat treatment or toluene/ethanol extraction).

\subsection{Heat treatment}

Heat treatment was performed on wood blocks $\left(10 \times 20 \times 50 \mathrm{~mm}^{3}\right.$, the longer dimension corresponding to the longitudinal direction) at $240{ }^{\circ} \mathrm{C}$ under nitrogen and at different times to reach mass losses of 5,10 and $15 \%$. The oven temperature was increased by
$20{ }^{\circ} \mathrm{C} \min ^{-1}$ from ambient to final temperature. Mass loss due to thermo-degradations during heat treatment was calculated according to the formula:

$$
M L(\%)=100 \times\left(m_{0}-m_{1}\right) / m_{0}
$$

where $m_{0}$ is the initial oven dried mass of the sample before heat treatment and $m_{1}$ the oven dried mass of the same sample after heat treatment.

\subsection{Fungal decay}

Heat treated wood blocks were cut into specimens of $5 \times 10 \times$ $25 \mathrm{~mm}^{3}$ for fungal durability evaluations, the longer dimension corresponding to the longitudinal direction. Petri dishes $(9 \mathrm{~cm}$ diameter) were filled with sterile medium $(20 \mathrm{~mL})$ prepared from malt $(40 \mathrm{~g})$ and agar $(20 \mathrm{~g})$ in distilled water $(1 \mathrm{~L})$ and inoculated with a piece of mycelium of a freshly grown Poria placenta (strain FPRL 280) culture. Petri dishes were incubated at $22{ }^{\circ} \mathrm{C}$ and $70 \% \mathrm{RH}$ until full colonization of the surface medium by the mycelium. Two untreated or heat treated cypress specimens were placed in each Petri dish and exposed to the brown rot fungus for 12 weeks. Each experiment was repeated four times. Pine (Pinus sylvestris L.) sapwood blocks $\left(5 \times 10 \times 25 \mathrm{~mm}^{3}\right.$, the longer dimension corresponding to the longitudinal direction) were used as virulence controls. At the end of test period, mycelia were removed and the blocks dried at $103{ }^{\circ} \mathrm{C}$ and weighed $\left(m_{2}\right)$. The weight loss caused by fungal degradation was calculated as follows:

$$
W L(\%)=100 \times\left(m_{0} \text { orl }-m_{2}\right) / m_{0} \text { orl }
$$

where $m_{0 \text { or } 1}$ are respectively the initial oven dried mass of control or heat treated wood blocks before fungal exposure and $m_{2}$ is the oven dried mass after fungal attack.

Similar procedure was used to evaluate the effect of toluene/ethanol extractives on wood natural durability. Extractives removal from blocks was performed by Soxhlet extraction with toluene/ethanol $(2 / 1, v / v)$ for $8 \mathrm{~h}$.

\subsection{Klason lignin determination}

Heat treated or untreated cypress samples were grounded and the sawdust obtained passed through a 40 mesh sieve. The sawdust was then Soxhlet extracted with toluene/ethanol $(2 / 1, v / v)(8 \mathrm{~h})$, with ethanol $(8 \mathrm{~h})$ and dried at $103{ }^{\circ} \mathrm{C}$ for $48 \mathrm{~h} .500 \mathrm{mg}$ of sawdust were mixed with $72 \% \mathrm{H}_{2} \mathrm{SO}_{4}(10 \mathrm{~mL})$ for $4 \mathrm{~h}$ at room temperature. The mixture was then diluted with $240 \mathrm{~mL}$ of distilled water, heated under reflux for $4 \mathrm{~h}$ and filtered. The Klason lignin residue was washed with hot water, dried at $103{ }^{\circ} \mathrm{C}$ and weighed. Holocellulose content was obtained by difference.

\subsection{GC-MS analysis}

Toluene/ethanol extract was used for GC-MS analysis. Samples were analysed as trimethylsilyl derivatives using the following procedure. In a screw-capped vial, a sample of approximately $1 \mathrm{mg}$ of dry extract was dissolved in $0.5 \mathrm{~mL}$ of anhydrous acetonitrile (Acros Organics) and $0.4 \mathrm{~mL}$ of N,O-bis-(trimethylsilyl) trifluoroacetamide 


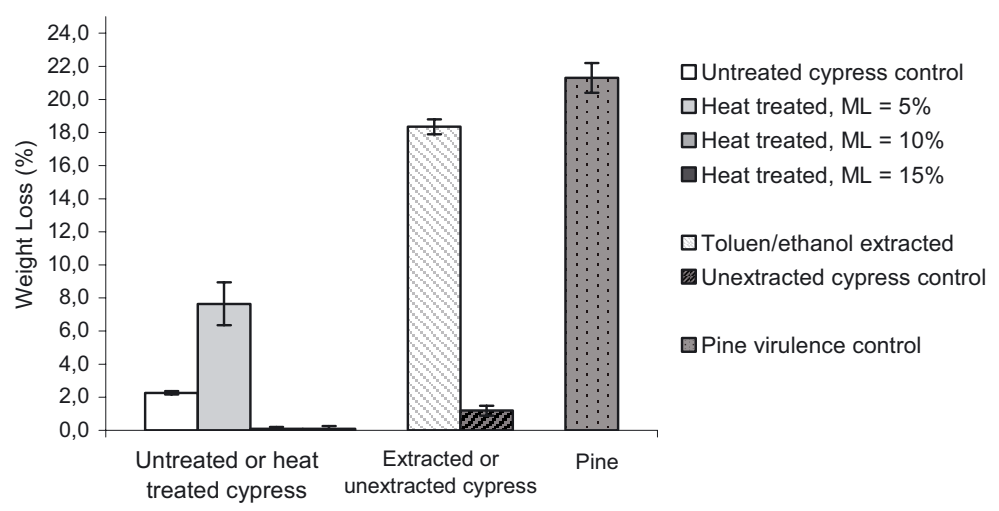

Figure 1. Weight losses of extracted or heat treated Cupressus lusitanica and control blocks after 12 weeks exposure to Poria placenta.

containing $1 \%$ trimethylchlorosilane (Acros Organics) was added. The solution was sonicated for about $1 \mathrm{~min}$ and heated at $60{ }^{\circ} \mathrm{C}$ for $20 \mathrm{~min}$. After evaporation of the solvent in a stream of dry nitrogen, the residue was diluted in $1 \mathrm{~mL}$ of anhydrous ethyl acetate. GCMS analysis was performed on a Clarus ${ }^{\circledR} 500 \mathrm{GC}$ gas chromatograph (Perkin Elmer Inc., USA) coupled to a Clarus ${ }^{\circledR} 500$ MS quadrupole mass spectrometer (Perkin Elmer Inc., USA). Gas chromatography was carried out on a $5 \%$ diphenyl $/ 95 \%$ dimethyl polysiloxane fused-silica capillary column (DB-5ms, $30 \mathrm{~m} \times 0.25 \mathrm{~mm}, 0.25 \mathrm{~mm}$ film thickness, J\&W Scientific, USA). The gas chromatograph was equipped with an electronically controlled split/splitless injection port. The injection $(1 \mu \mathrm{L})$ was performed at $250{ }^{\circ} \mathrm{C}$ in the split mode (split flow of $40 \mathrm{~mL} / \mathrm{min}$ ). Helium was used as carrier gas, with a constant flow of $1 \mathrm{~mL} / \mathrm{min}$. The oven temperature program was as follows: $60{ }^{\circ} \mathrm{C}$ constant for $2 \mathrm{~min}, 60{ }^{\circ} \mathrm{C}$ to $300{ }^{\circ} \mathrm{C}$ at a rate of $10^{\circ} \mathrm{C} / \mathrm{min}$ and then constant for $9 \mathrm{~min}$. Ionisation was achieved under the electron impact mode (ionisation energy of $70 \mathrm{eV}$ ). The source and transfer line temperatures were $250{ }^{\circ} \mathrm{C}$ and $330{ }^{\circ} \mathrm{C}$, respectively. Detection was carried out in scan mode: $\mathrm{m} / \mathrm{z} 35$ to $\mathrm{m} / \mathrm{z} 700$. The detector was switched off in the initial $2 \mathrm{~min}$ (solvent delay). Compounds were identified by comparison with spectra from the NIST (US National Institute of Standards and Technology, Gaithersburg, MD, USA) mass spectral library.

\subsection{Fungal growth inhibition test}

Mycelium was grown in $9 \mathrm{~cm}$ Petri dishes filled with $20 \mathrm{~mL}$ of malt-agar medium prepared as in Section 2-3 above containing 50, $100,250,500$ or 1000 ppm of toluene/ethanol extracts. For this purpose, a $10000 \mathrm{ppm}$ stock solution was prepared by dissolving $100 \mathrm{mg}$ of extracts in ethanol/water mixture $(1 / 4, v / v)$ in a $100 \mathrm{~mL}$ volumetric flask. The different concentrations used for the growth inhibition tests were obtained by dilution from this stock. Controls were made from the same solvent (ethanol/water mixture). Introduction of the extracts was carried out after medium sterilization $\left(20 \mathrm{~min}, 120^{\circ} \mathrm{C}, 1\right.$ bar) by addition of the necessary quantity of extracts. Plates were inoculated in their centre with a small portion of a malt agar freshly grown $\mathrm{Po}$ ria placenta colony. The cultures were kept at $22{ }^{\circ} \mathrm{C}$ and $70 \% \mathrm{RH}$. Growth inhibition was determined when the diameter of the control culture reached $9 \mathrm{~cm}$ by measuring the diameter of the colony estimated from the mean of three diameters and calculated according to the following formula:

$$
\text { Growth Inhibition }(\%)=100 \times\left(1-d_{1} / d_{0}\right)
$$

where $d_{0}$ is the diameter of the control culture and $d_{1}$ the diameter of the culture in the presence of the extracts. EC50 (50\% reduction in a radial hyphal growth) with $95 \%$ confidence limits was estimated by probit analysis (Finney, 1971). Each experiment was duplicated.

\section{RESULTS AND DISCUSSION}

\subsection{Heat treatment and fungal decay}

Weight losses of heat treated cypress blocks are presented in Figure 1. Contrary to what was initially expected, heartwood of Cupressus lusitanica was resistant to decay. Surprisingly, slightly heat treated samples with mass losses of 5\% were susceptible to fungal degradation (compare weight losses up to $8 \%$ for heat treated samples to $2 \%$ for controls). Increase of the heat treatment duration to mass losses of 10 to $15 \%$ improves wood durability, which becomes totally resistant to decay as generally reported in the literature (Hakkou et al., 2006; Militz, 2002; Patzelt et al., 2002; Welzbacher and Rapp, 2007). This behaviour can be explained by two opposite effects. The first few minutes of heat treatment leads to evaporation of volatile extractives, which decreases wood durability, while longer heating time induces thermo-degradation reactions of wood cell wall polymers explaining improvement of durability. Thermo-degradation reactions result in an increase of Klason lignin content and a decrease of holocellulose content in wood (Fig. 2) as reported in the literature for other wood species (Alén et al., 2002; Boonstra et al., 2006; Hakkou et al., 2005; Nguila Inari et al., 2007; Wikberg and Maunu, 2004; Yildiz et al., 2006).

\subsection{Effect of extractives on natural durability}

To confirm the role of extractives on wood natural durability, extractives were removed by Soxhlet extraction and wood durability against Poria placenta tested (Fig. 1). Extraction was performed with toluene/ethanol mixture to remove both hydrophilic and lipophilic extractives leading to $4.7 \%$ of extractives. Extracted cypress heartwood was severely degraded by Poria placenta as demonstrated by the significant weight 


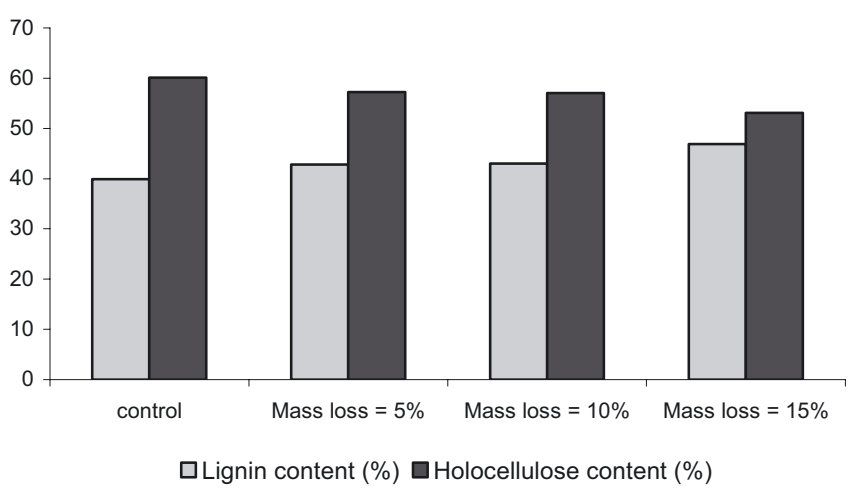

Figure 2. Lignin and holocellulose contents for control and heat treated Cupressus lusitanica blocks.

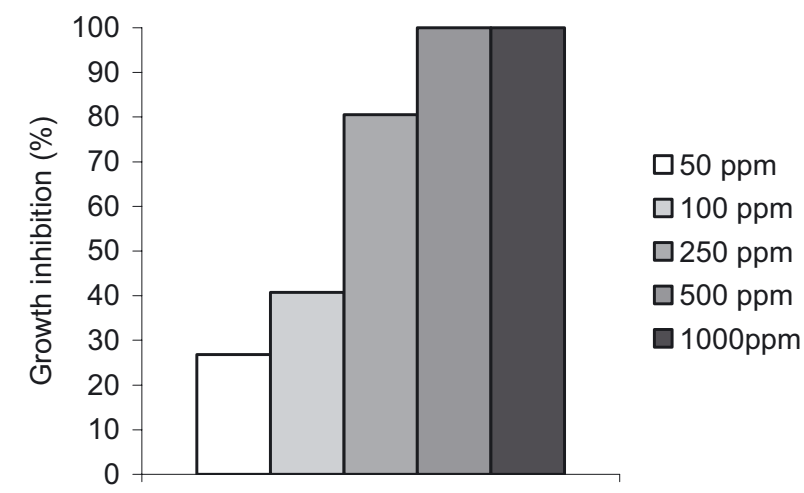

Figure 3. Effects of cypress toluene/ethanol extractives on growth of Poria placenta.

losses recorded after 12 weeks exposure. As observed for other wood species, natural durability is attributed to the presence of extractives, which act as biocides to prevent wood biodegradation (Celimene et al., 1999; Daniels and Russels, 2007; Haupt et al., 2003; Lukmandaru and Takahashi, 2009; Mburu et al., 2007; Neya et al., 2004; Reyes Chilpa et al., 1998; Windeisen et al., 2002). To confirm the effect of the extractives on wood durability, fungal growth inhibition assays were conducted. Extracts were tested at different concentrations from 50 to 1000 ppm on Poria placenta (Fig. 3). Development of the mycelium was totally inhibited at concentrations of 500 and 1000 ppm, while lower concentrations lead to partial inhibition of the fungal growth. $\mathrm{EC}_{50}$ with $95 \%$ confidence limits was estimated to $103 \mathrm{ppm}$.

\subsection{GC-MS analysis}

Extraction of Cupressus lusitanica sawdust with toluene/ethanol lead to $6.5 \%$ of extracts, which were subjected to GC-MS analysis (Tab. I). Different compounds were identified in the mixture among which a large amount of benzaldehyde and terpenic compounds like cedrol, agathadiol, epimanool, bornyl acetate, $\alpha$-cedrene, $\beta$-cedrene and $\alpha$-cedrene oxide (Fig. 4). Cedrol, which represents $14.5 \%$ of
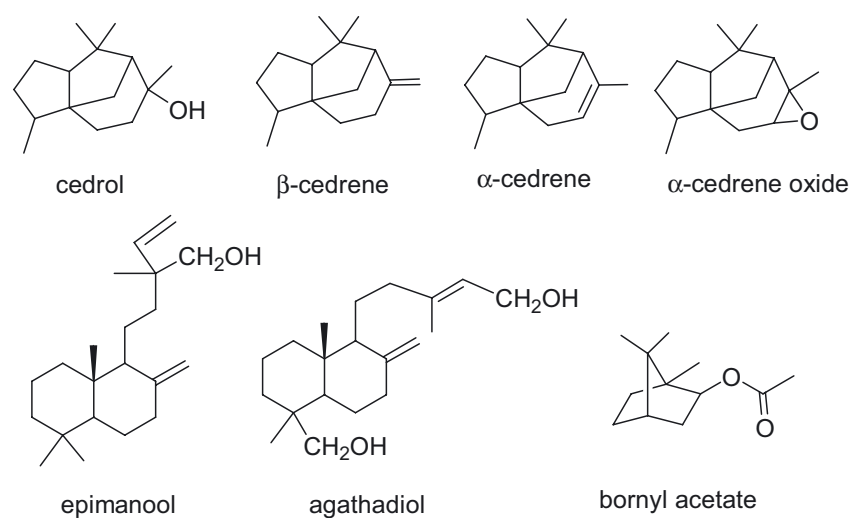

Figure 4. Main terpenic compounds identified in cypress toluene/ethanol extractives.

Table I. GC-MS analysis of toluene/ethanol extracts of Cupressus lusitanica.

\begin{tabular}{|c|c|c|}
\hline Retention time (min.) & Coumpound & Amount $(\%)^{a}$ \\
\hline 2.83 & 4-hydroxy-butanoic acid & 0.68 \\
\hline 3.26 & Benzaldehyde & 34.36 \\
\hline 3.94 & Benzyl Alcohol & 19.06 \\
\hline 4.45 & Unknown & 0.64 \\
\hline 5.21 & Benzyl alcohol (1TMS) & 2.27 \\
\hline 5.35 & Unknown & 0.39 \\
\hline 6.42 & O-Methylthymol & 1.85 \\
\hline 7.10 & Bornyl acetate & 1.56 \\
\hline 8.57 & 6-tert-Butyl-m-Cresol (mixture of) & 2.07 \\
\hline 8.65 & Vanillin & 1.04 \\
\hline 8.94 & $\alpha$-Cedrene & 0.75 \\
\hline 9.06 & $\beta$-cedrene & 0.40 \\
\hline 9.65 & Unknown & 0.43 \\
\hline 10.92 & Hexadec-1-ene & 3.17 \\
\hline 11.40 & Cedrol & 6.15 \\
\hline 11.52 & $\alpha$-Cedrene oxide & 0.55 \\
\hline 11.57 & Unknown & 1.87 \\
\hline 11.76 & Unknown & 0.41 \\
\hline 11.91 & Unknown & 0.86 \\
\hline 12.34 & Unknown & 0.89 \\
\hline 12.80 & Unknown & 0.94 \\
\hline 13.18 & fatty chain & 1.42 \\
\hline 13.70 & Unknown & 0.65 \\
\hline 15.24 & fatty chain & 0.34 \\
\hline 15.70 & Palmitic acid (1 TMS) & 0.44 \\
\hline 16.04 & Epimanool & 1.15 \\
\hline 17.64 & Unknown & 0.36 \\
\hline 17.95 & Unknown & 0.44 \\
\hline 18.30 & steroid decomposition product & 1.79 \\
\hline 18.77 & Agathadiol & 2.15 \\
\hline
\end{tabular}

${ }^{a}$ Relative concentration (\%) were determined from the TIC. Total $=89.09 \%$. 
the whole extract, has been reported to possess fungicidal and fungistatic properties (Aleu et al., 2001; Engstrom et al., 1999) and is therefore believed to be responsible in great part to the cypress natural durability. Other components like bornyl acetate, $\alpha$-cedrene or $\beta$-cedrene have been reported to be present in the composition of essential oils and possessing antimicrobial or antifungal properties (Jasicka-Misiaka et al., 2004; Jeong et al., 2007; Kordali et al., 2008; Kuźma et al., 2009; Rançić, et al., 2005). GC-MS chromatograms of toluene/ethanol extractives from untreated and slightly heat treated cypress samples $(M L=5 \%)$ are presented in Figure 5 . The results clearly indicated a modification of extractives composition after heat treatment. Low molecular weight volatile extractives like cedrol (bp $=273{ }^{\circ} \mathrm{C}$ ), $\alpha$-cedrene $\left(\mathrm{bp}=261{ }^{\circ} \mathrm{C}\right), \beta$-cedrene $\left(\mathrm{bp}=263{ }^{\circ} \mathrm{C}\right)$, bornyl acetate $\left(\mathrm{bp}=228^{\circ} \mathrm{C}\right)$ or benzaldehyde $\left(\mathrm{bp}=178^{\circ} \mathrm{C}\right)$ disappear from heat treated wood, while some new products like ketones and lignin degradation products appear (Tab. II). After heat treatment, vanillin becomes the most important compounds in the toluene/ethanol extracts. Extractives, and particularly cedrol and other diterpenic compounds present in high quantity in the heartwood of Mexican cypress, seem therefore responsible for wood natural durability. On the basis of this study, conflicting reports concerning natural durability of Cupressus lusitanica can be attributed to the presence of these extractives, which can partially be eliminated during drying processes, storage or wood weathering leading to variations of natural durability.

\section{CONCLUSION}

This study has provided new insight on the reason of the natural durability of Cupressus lusitanica heartwood for which contradictory data have been reported in the literature. Extractives present in the heartwood are responsible for wood natural durability. GC-MS analysis of toluene/ethanol extractives indicated the presence of several diterpenic compounds, among which cedrol present in large amount. Heat treatment on wood was initially investigated due to the conflicting literature reports on cypress natural durability. Induced volatilization of most of these extractives which occurred in the first few minutes of heat treatment is responsible for the observed decrease in wood durability. Increased durability at longer periods of heat treatment is due to thermo-degradation of wood cell wall polymers. Contribution of extractives to wood durability was investigated on blocks subjected to toluene/ethanol extraction then exposed to the brown rot fungus Poria placenta. Results showed a strong degradation of extracted wood blocks, while unextracted blocks were resistant to decay. Effect of extractives on wood durability was confirmed by mycelium growth inhibition assays indicating more or less important growth inhibition according to the tested concentration. All these data suggest that variation of extractives content, which may be modified through evaporation of more volatile compounds during drying processes, storage or wood weathering, could be at the origin of the conflicting reports described in the liter-
Table II. GC-MS analysis of toluene/ethanol extracts of heat treated Cupressus lusitanica (mass loss $=5 \%$ ).

\begin{tabular}{|c|c|c|}
\hline $\begin{array}{l}\text { Retention time } \\
(\mathrm{min})\end{array}$ & Coumpound & $\begin{array}{l}\text { Amount } \\
(\%)^{a}\end{array}$ \\
\hline 3.90 & Unknown & 0.92 \\
\hline 5.44 & Unknown & 0.47 \\
\hline 7.48 & Unknown & 0.58 \\
\hline 8.26 & Unknown & 0.84 \\
\hline 8.54 & Unknown & 0.50 \\
\hline 8.72 & Vanillin & 27.42 \\
\hline 8.97 & Unknown & 0.74 \\
\hline 9.09 & Unknown & 2.76 \\
\hline 9.40 & Unknown & 2.05 \\
\hline 9.61 & Methylvanillin (mixture of) & 6.27 \\
\hline 9.77 & Acetovanillone & 3.25 \\
\hline 10.10 & Methyl vanillic ester & 1.90 \\
\hline 10.28 & Vanillin (1TMS) & 3.52 \\
\hline 10.42 & Unknown & 0.55 \\
\hline 10.51 & Unknown & 0.38 \\
\hline 10.69 & Unknown & 0.72 \\
\hline 10.90 & 3-methylprotocatechuic ester & 8.15 \\
\hline 10.96 & Vanillin derivative & 3.87 \\
\hline 11.11 & Unknown & 0.39 \\
\hline 11.25 & Unknown & 0.74 \\
\hline 11.32 & Unknown & 0.84 \\
\hline 11.54 & 9-Cedranone & 4.72 \\
\hline 11.58 & 3,4,5-trimethoxy-phenylpropanoic acid & 8.01 \\
\hline 11.78 & $\begin{array}{l}\text { 3,5,6,7,8,8a-hexahydro-4,8a-dimethyl-6- } \\
\text { (1-methylethenyl)-2(1H)Naphthalenone }\end{array}$ & 2.79 \\
\hline 11.96 & Unknown & 0.70 \\
\hline 12.09 & Longipinocarvone & 2.51 \\
\hline 12.33 & Unknown & 0.41 \\
\hline 12.63 & Velleral & 0.93 \\
\hline 12.71 & 4-Hydroxy-2-methoxycinnamaldehyde & 1.34 \\
\hline 12.83 & Vanillic acid (2 TMS) & 0.42 \\
\hline 13.01 & 2.3-dimethoxy-phenylbutyric acid & 0.62 \\
\hline 13.10 & Unknown & 0.39 \\
\hline 13.17 & Unknown & 0.43 \\
\hline 13.35 & Unknown & 0.38 \\
\hline 13.67 & Unknown & 0.37 \\
\hline 13.96 & Dialkylphtalate & 0.63 \\
\hline 14.05 & Unknown & 0.75 \\
\hline 14.44 & Unknown & 0.50 \\
\hline 14.93 & Unknown & 0.40 \\
\hline 16.02 & Unknown & 0.62 \\
\hline 20.02 & Unknown & 0.39 \\
\hline 20.94 & Sugiol & 0.40 \\
\hline
\end{tabular}

${ }^{a}$ Relative concentration (\%) were determined from the TIC. Total $=94.57 \%$.

ature on Cupressus lusitanica heartwood durability. Our study suggests also that heat treatment could be a valuable method to improve wood durability avoiding thus problems of variability associated to the presence of volatile extractives which can influence durability. 


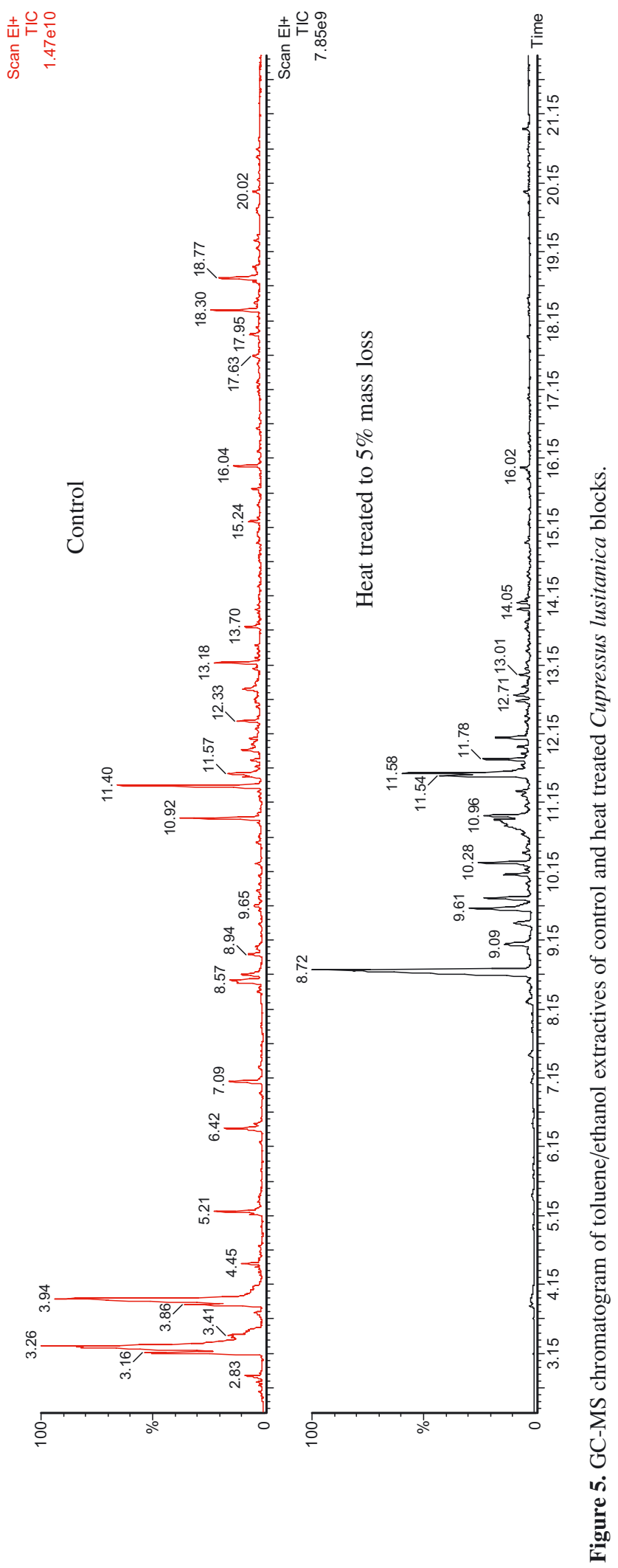


Acknowledgements: This research was supported by a post-doctor grant for the first author from the Agence Universitaire de la Francophonie (AUF) and a grant from the French government through the Embassy in Nairobi for the second author. The authors would like to acknowledge the financial support of the CPER 2007-2013 "Structuration du Pôle de Compétitivité Fibres Grand'Est".

\section{REFERENCES}

Aleu J., Hanson J.R., Hernandez Galan R., and Collado I.G., 2001. Biotransformation of the fungistatic sesquiterpenoids patchoulol,ginsenol, cedrol and globulol by Botrytis cinerea. J. Mol. Catal B Enzym. 11: 329-334.

Alén R., Kotilainen R., and Zaman A., 2002. Thermochemical behaviour of Norway spruce (Picea abies) at $180-225^{\circ} \mathrm{C}$. Wood Sci. Technol. 36: $163-171$.

Boonstra M.J., Pizzi A., and Rigolet S., 2006. Correlation of ${ }^{13}$ C-NMR analysis with fungal decay tests of polymeric structural wood constituents. I. Basidiomycetes. J. Appl. Polym. Sci. 101: 2639-2649.

Celimene C.C., Micales J.A., Ferge L., and Young R., 1999. Efficacy of pinosylvins against white- rot and brown- rot fungi. Holzforschung 53: 491-497.

Daniels C.R. and Russell J., 2007. Analysis of Western Redcedar (Thuja plicata Donn) heartwood components by HPLC as a possible screening tool for trees with enhanced natural durability. J. Chromatogr. Sci. 45: 281-285.

Engstrom K., Widmark A.K., Brishammar S., and Helmersson S., 1999. Antifungal activity to Phytophthora infestans of sesquiterpenoids from infected potato tubers. Potato Research 42: 43-50.

Finney D.J., 1971. Probit analysis, Cambridge University Press, Cambridge, $318 \mathrm{p}$.

Hakkou M., Pétrissans M., Zoulalian A., and Gérardin P., 2005. Investigation of Wood wettability changes during heat treatment on the basis of chemical analysis. Polym. Degrad. Stab. 89: 1-5.

Hakkou M., Pétrissans M., Gérardin P., and Zoulalian A., 2006. Investigations of the reasons for fungal durability of heat-treated beech wood. Polym. Degrad. Stab. 9: 393-399.

Haupt M., Leithoff H., Meier D., Puls J., Richter H.G., and Faix O., 2003. Heartwood extractives and natural durability of plantation grown teakwood (Tectona grandis L.) - a case study. Holz Roh- Werkst 61: 473-474.

Jasicka-Misiaka I., Lipoka J., Nowakowskaa E.W., Wieczoreka P.P., Młynarzb P., and Kafarskia P., 2004. Antifungal activity of the carrot seed oil and its major sesquiterpene compounds. Z. Naturforsch. 791-796.

Jeong S., Lim J.P., and Hoon Jeon H., 2007. Chemical composition and antibacterial activities of the essential oil from Abies koreana. Phytother. Res. 21: 1246-1250.

Kordali S., Cakir A., Ozer H., Cakmakci R., Kesdek M., and Mete E., 2008. Antifungal, phytotoxic and insecticidal properties of essential oil isolated from Turkish Origanum acutidens and its three components, carvacrol, thymol and p-cymene. Bioresour. Technol. 99: $8788-8795$.

Kuźma K.L., Kalemba D., Różalski M., Różalska B., WięckowskaSzakiel M., Krajewska U., and Wysokińska H., 2009. Chemical composition and biological activities of essential oil from Salvia sclarea plants regenerated in vitro. Molecules 14: 1438-1447.
Lukmandaru G. and Takahashi K., 2009. Variation in the natural termite resistance of teak (Tectona grandis Linn. fil.) wood as a function of tree age. Ann. For. Sci. 65: 708.

Mburu F., Dumarçay S., and Gérardin P., 2007. Evidence of fungicidal and termicidal properties of Prunus africana heartwood extractives. Holzforschung 61: 323-325.

Mburu F., Dumarçay S., Huber F., Pétrissans M., and Gérardin P., 2007. Evaluation of thermally modified Grevillea robusta heartwood as an alternative of shortage of wood resource in Kenya: characterisation of physicochemical properties and improvement of bio-resistance. Bioresour. Technol. 98: 3478-3486.

Militz H., 2002. Thermal treatment of wood: European processes and their background. International Research Group on Wood Preservation, IRG/WP 02-40241.

Neya B., Hakkou M., Pétrissans M., and Gérardin P., 2004. On the durability of Burkea africana heartwood: evidence of biocidal and hydrophobic properties responsible for durability. Ann. For. Sci. 61: $277-282$.

Nguila Inari G., Mounguengui S., Dumarçay S., Pétrissans M., and Gérardin P., 2007. Evidence of char formation during heat treatment by mild pyrolysis. Polym. Degrad. Stab. 92: 997-1002.

Patzelt M., Stingl R., and Teischinger A., 2002. Termische Modifikation von Holz und deren Einflu $\beta$ auf ausgewählte Holzeigenschaften, In Modifiziertes Holz Eigenschaften und Märkte, Lignovisionen Band 3, pp. 101-149.

Rančić A., Soković M., Vukojević J., Simić A., Marin P., DuletićLaušević S., and Djoković D., 2005. Chemical composition and antimicrobial activities of essential oils of Myrrhis odorata (L.) scop, Hypericum perforation $\mathrm{L}$ and Helichrysum arenarium (L.) Moench. JEOR 17: 341-345.

Reyes Chilpa R., Gomez-Garibay F., Moreno-Tores G., Jimenez-Estrada M., and Quiroz-Vasquez R.I., 1998. Flavonoids and isoflavonoids with antifungal properties from Platymiscium yucatanum heartwood. Holzforschung 52: 459-462.

Scheffer T.C. and Morrell J.J., 1998. Natural durability of wood: a worldwide checklist of species. Forest Research Laboratory, Oregon State University, Research Contribution 22, 58 p.

Welzbacher C. and Rapp A., 2007. Durability of thermally modified timber from industrial-scale processes in different use classes: Results from laboratory and field tests. Wood Mater. Sci. Eng. 2: 4-14.

Venkatasamy R., 2006. Comparing microbial colonisation and decay rates of wood from sound and aphid-killed Kenyan grown Mexican cypress (Cupressus lusitanica). International Research Group on Wood Preservation IRG/WP 06-10599.

Wikberg H. and Maunu S.L., 2004. Characterisation of thermally modified hard- and soft woods by ${ }^{13} \mathrm{C}$ CPMAS NMR. Carbohydr. Polym. 58: 461-466.

Windeisen E., Wegener G., Lesnino G., and Schumacher P., 2002. Investigation of the correlation between extractives content and natural durability in 20 cultivated larch trees. Holz Roh- Werkst 60: 373374.

Yildiz S., Gezer E.D., and Yildiz U.C., 2006. Mechanical and chemical behaviour of spruce wood modified by heat. Build. Environ. 41: 1762-1766. 